\title{
Spatial and temporal use of spawning aggregation sites by the tropical sciaenid Protonibea diacanthus
}

\author{
Jayson M. Semmens ${ }^{1, *}$, C. D. Buxton ${ }^{1}$, E. Forbes ${ }^{1}$, M. J. Phelan ${ }^{2,3}$ \\ ${ }^{1}$ Marine Research Laboratory, Tasmanian Aquaculture and Fisheries Institute, University of Tasmania, Private Bag 49, \\ Hobart, Tasmania 7001, Australia \\ ${ }^{2}$ Department of Primary Industries, Fisheries and Mines, GPO Box 3000, Darwin, Northern Territory 0801, Australia \\ ${ }^{3}$ Present address: Tourism and Visitor Services, Environmental Protection Agency, Whitsunday Office, PO Box 332, \\ Airlie Beach, Queensland 4802, Australia
}

\begin{abstract}
Fish spawning aggregations (FSA) are generally spatially and temporally predictable, making them particularly vulnerable to fishing, which is capable of rapidly removing a significant proportion of the aggregated adults and reducing egg production. These effects may cause the loss of the aggregation altogether. In the Northern Territory (NT), Australia, repeated fishing of known aggregations of the tropical sciaenid species, the blackspotted croaker Protonibea diacanthus, is probably unsustainable, particularly given this species' decline elsewhere. Acoustic monitoring was used to examine the temporal and spatial movement patterns and site fidelity of $P$. diacanthus in the NT. Fish were only detected at their respective aggregations, providing no evidence of large-scale movements between FSA. There was evidence for behavioural polymorphism in the aggregations, and fish monitored for $\geq 1 \mathrm{yr}$ showed decreased presence during cooler months and increased presence during warmer months when peak spawning occurs. The tidal cycle significantly influenced the detection of tagged fish, with detections peaking on running tides, the peak period for catching $P$. diacanthus, suggesting that this is when they feed. This study has provided important information on the connectivity and dynamics of $P$. diacanthus aggregations in the NT, including crucial information for implementing appropriate management strategies for this vulnerable species. There appears to be little interchange of adult $P$. diacanthus at the spatial scale examined, which suggests that the separate FSA examined support separate adult populations. The presence of seemingly separate spawning populations of $P$. diacanthus has significant implications for their management, with the potential for each aggregation to be vulnerable to localised depletion.
\end{abstract}

KEY WORDS: Spawning aggregation $\cdot$ Site fidelity $\cdot$ Acoustic monitoring $\cdot$ Sciaenidae $\cdot$ Fisheries management $\cdot$ Movement $\cdot$ Tidal cycle

\section{INTRODUCTION}

Fish spawning aggregations (FSA) may be transient and individuals travel distances of hundreds of kilometres and aggregate for a period of days or weeks, or they may be resident in which case individuals have extended spawning seasons (months), travel short distances (e.g. 10 to $100 \mathrm{~m}$ ) and aggregate for minutes to hours (see review by Domeier \& Colin 1997). Whether transient or resident, spawning aggregations are generally spatially and temporally predictable. As such, FSA are particularly attractive targets to fishers who are able to locate the aggregations and obtain a predictably high catch per unit effort (Claydon 2004, Sadovy \& Domeier 2005, Phelan 2007). This makes spawning aggregations particularly vulnerable, with heavy fishing capable of rapidly removing a significant proportion of the aggregated adults and reducing egg production (Sadovy \& Domeier 2005). Selective fishing of FSA may also truncate the size and age structure through targeting of larger fish (Beets \& Friedlander 1992, Sala et al. 2001), leaving the population less fecund (Eklund et al. 2000, Sala et al. 2001), and may alter genetic composition (Smith et al. 1991) and skew 
the sex ratio (Coleman et al. 1996). These combined effects may cause the loss of the FSA altogether (e.g. Totoaba macdonaldi, Cisneros-Mata et al. 1995; Epinephelus striatus, Sadovy \& Eklund 1999, Sala et al. 2001; Bahaba taipingensis, Sadovy \& Cheung 2003), from which they may not recover (Sadovy \& Eklund 1999).

The potentially catastrophic effects of overfishing on FSA may be prevented by seasonal or spatial closures and market and/or gear restrictions (see reviews by Sadovy \& Cheung 2003, Claydon 2004, Sadovy \& Domeier 2005). Effective FSA management relies on some knowledge of factors such as the geographic extent from which reproductive populations are drawn (catchment area), site fidelity, individual participation rate, potential sex-specific residency times and where the resultant larvae settle (Zeller 1997, Sadovy \& Domeier 2005).

The blackspotted croaker Protonibea diacanthus (a tropical sciaenid), grows to a large size $(\leq 1.5 \mathrm{~m}$ total length [TL] and $\leq 45 \mathrm{~kg}$ ) and aggregates to spawn in inshore Australian waters from central Queensland to northern Western Australia (Phelan 2007, Phelan et al. 2008). In the Northern Territory (NT) P. diacanthus are caught at FSA year-round. Spawning takes place between August and January and peaks in December and January (Phelan \& Errity 2008).

Sciaenid fishes are widely distributed in tropical and subtropical waters (Trewavas 1977, Sasaki 2001) and aggregate to spawn (e.g. Saucier \& Baltz 1993, Griffiths \& Hecht 1996, Sadovy \& Cheung 2003, Norbis \& Verocai 2005). These aggregations often form the basis of commercial, recreational or indigenous fisheries (e.g. Mohan 1991, Apparao et al. 1992, De Bruin et al. 1994, Williams 1997). Despite being fast growing and highly fecund, sciaenids are particularly vulnerable to FSA overfishing worldwide because aggregations are largely confined to heavily exploited coastal waters (Sadovy \& Cheung 2003).

As a result, at least 11 sciaenid species are currently vulnerable throughout all or parts of their geographic distribution due to overfishing, including the 2 species, Totoaba macdonaldi and Bahaba taipingensis, which are close to extinction (see Sadovy \& Cheung 2003 for a review). Included within those 11 species is Protonibea diacanthus. This species is now under threat and there is no longer a significant fishery in either Hong Kong (Sadovy \& Cheung 2003) or India (James 1992) where it once thrived. In Australia anecdotal evidence suggests that intensive fishing has severely affected several annual $P$. diacanthus FSA along the eastern coast of Queensland (Bowtell 1998 cited in Phelan 2007) and the far northern coast (Phelan 2007). After 5 decades of increased fishing pressure Phelan (2007) documented a reduction in the number, size and age structure of $P$. diacanthus caught. A decrease in the number of mature fish, the age of first maturity and the duration fish were present at the FSA was also documented.

Protonibea diacanthus are a substantial component of both the commercial and recreational inshore fisheries catch in the NT, with fishers targeting spatially and temporally predictable FSA. The combined harvest of $P$. diacanthus in this region rose from $443 \mathrm{t}$ in 1995 to at least $667 \mathrm{t}$ in 2005 (Phelan \& Elphick 2006). During this same period, commercial harvest of $P$. diacanthus in the coastal line fishery increased by $480 \%$ and accounted for $87 \%$ of the total catch in 2005 (Phelan \& Elphick 2006). Recreational fishing surveys in 2000 estimated the $P$. diacanthus catch to be approximately one-third of the total recreational catch, exceeding that of the total commercial catch by almost $250 \mathrm{t}$ (Coleman 2004).

Repeated harvesting of these FSA is probably unsustainable, particularly given the decline of Protonibea diacanthus at other localities (James 1992, Bowtell 1998 cited in Phelan 2007, Sadovy \& Cheung 2003, Phelan 2007). Although declines may be the result of other factors, decreases of almost 10 and $25 \%$ in the recreational (1996 to 2000, Coleman 1998, 2004) and commercial (2004 to 2006, Phelan et al. 2008b) harvests suggest that $P$. diacanthus may already be overfished. Importantly, Phelan (2007) noted that a 2 yr moratorium on fishing an overfished $P$. diacanthus FSA in far northern Queensland only resulted in a slight population recovery. Thus, any management action to protect these FSA needs to be taken long before changes in the population structure occur.

This study used acoustic telemetry to examine the temporal and spatial movement patterns of Protonibea diacanthus within and between 2 of the 3 known major FSA in the NT. The FSA fidelity of $P$. diacanthus was studied to help determine whether the FSA support separate populations and, with the level of site fidelity of individuals, to determine the effectiveness of management measures such as spatial and temporal closures.

\section{MATERIALS AND METHODS}

Channel Point FSA site, acoustic receiver deployment and range testing. The Channel Point FSA site $\left(13^{\circ} 09^{\prime} \mathrm{S}, 130^{\circ} 04.80^{\prime} \mathrm{E}\right)$ (Fig. 1a) is defined by a 35 to $40 \mathrm{~m}$ deep channel running in a NW to SE plane for approximately $2 \mathrm{~km}$, with shallow (5 to $10 \mathrm{~m}$ ) flats on either side of the channel (Meekan et al. 2008) (Fig. 1b). On the eastern side, the channel has steep rock walls that rise almost vertically from the bottom, forming a ledge between the deep part of the channel 


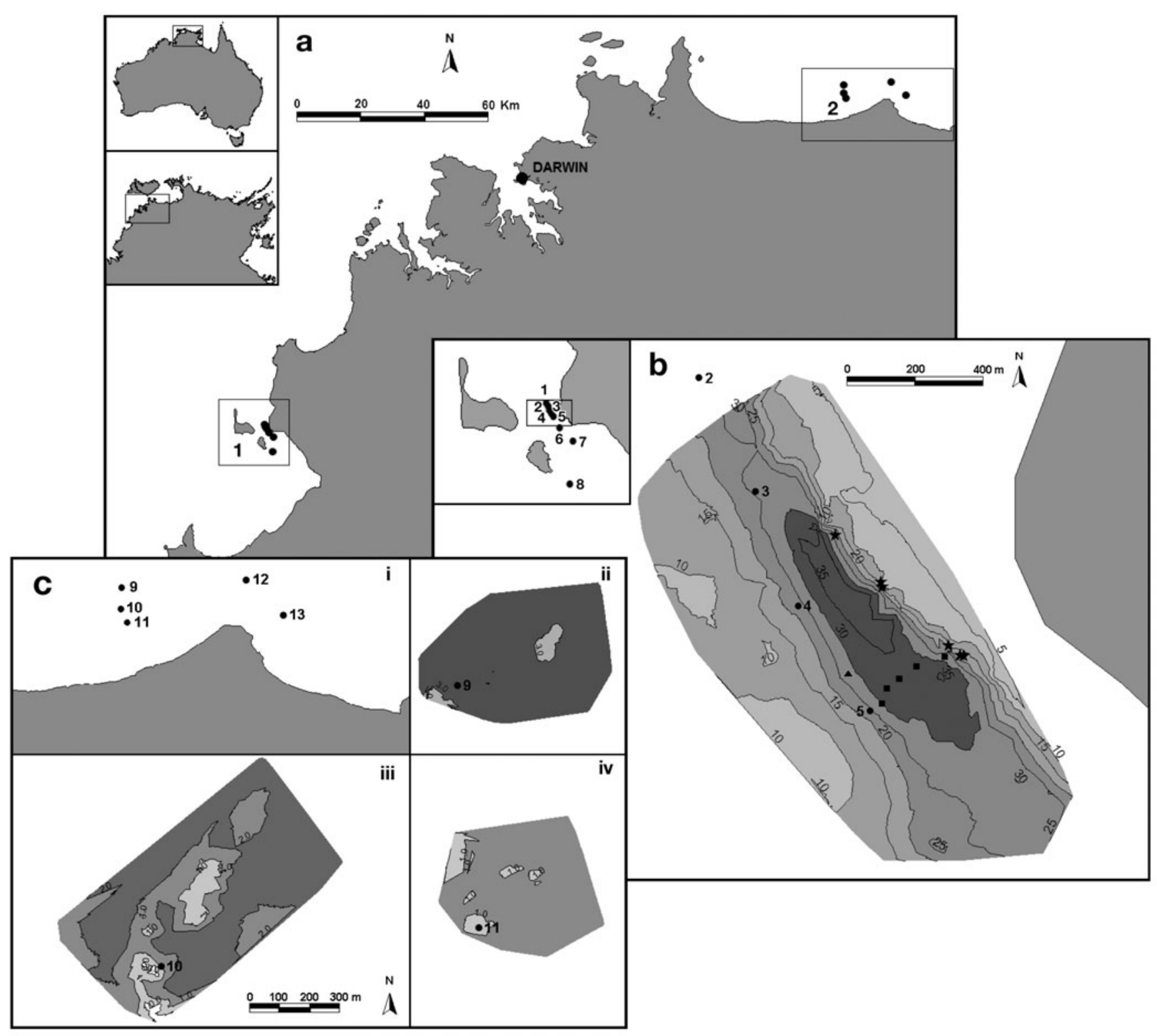

Fig. 1. (a) Northern Territory (NT), Australia, indicating placement and identification numbers of individual receivers $(\bullet)$. Inset 1: Channel Point FSA; inset 2: Chambers Bay FSA. Insets in upper left: general location of study area (upper) in Australia, and (lower) in NT. (b) Channel Point FSA bathymetric map indicating placement and identification of individual receivers. Numbered lines: depth contours. $(\star)$ Fish tagging sites. $(\boldsymbol{\Lambda}, \boldsymbol{\square})$ Positions of the receiver and tags used in the post-deployment receiver range test, respectively. Inset: general region and placement and identification of individual receivers, with the scale matching that shown in (a). (c) Panel i: Chambers Bay FSA indicating placement and identification of individual receivers, with the scale matching that shown in (a); Panels ii to iv: bathymetric maps of the reef surrounding Receivers 9 to 11, respectively. Numbered lines: depth contours. Scale shown in Panel iii also applies to Panels ii and iv

and the shallow flats. The commercial fishers catch mature aggregating Protonibea diacanthus on this ledge in approximately $10 \mathrm{~m}$ of water (see Fig. 1b). Currents at Channel Point flow in a NW direction following the channel, with velocities of 0.3 to $1.0 \mathrm{~m} \mathrm{~s}^{-1}$ on the ebb tides (Meekan et al. 2008). Five acoustic receivers (VR2s; Vemco) were deployed in November 2004 less than $400 \mathrm{~m}$ apart (based on pre-deployment range testing in Darwin Harbour, August 2004) along the western edge of the channel, between 170 and $350 \mathrm{~m}$ from the eastern edge of the channel (Receivers 1 to 5, Fig. 1b). Receiver 1 was removed in April 2005 as it had no data and Receiver 3, which was not retrieved between 10 April and 27 October 2005, was replaced. Receivers 6 to 8 (Fig. 1a,b) were deployed south of the aggregation in November 2004. Receiver 6 had no data when retrieved in 10 April, but was not retrieved after this date. 
A post-deployment trial of the receiving range of the Channel Point FSA array was conducted in May 2007 to determine the performance of the receivers over a monthly tidal regime. A VR2 was moored approximately $130 \mathrm{~m}$ northwest of the site where Receiver 5 was previously located (Fig. 1b). Five fish transmitters were moored across the channel at approximately $1 \mathrm{~m}$ above the substrate at set distances from the receiver (Fig. 1b) for approximately 1 mo.

Channel Point FSA tagging. Forty mature Protonibea diacanthus (TL from 940 to $1220 \mathrm{~mm}$; mean \pm $\mathrm{SE}=1080 \pm 12 \mathrm{~mm}$ ) were captured on hook and line in water $\leq 10 \mathrm{~m}$ deep to avoid barotrauma (see Phelan et al. 2008a) between 6 December 2004 and 27 October 2005 (see Fig. 1b for tagging locations). All fish were surgically implanted (tagged) with V16-5H transmitters (Vemco), which emitted a unique identifiable coded signal at a random interval of 60 to $180 \mathrm{~s}$ and had an estimated life of $900 \mathrm{~d}$. Surgery was done without anaesthetic, as fish went into a deep torpor when turned upside down and surgery trials in December 2004 showed that there was a high risk of death of $P$. diacanthus after anaesthesia. After surgery, all fish were tagged with an external dart tag (Hallprint) for ease of identification if recaptured, and then released without holding at the capture site (see Fig. $1 b, c)$ if they were assessed to be in good condition. On average, the whole process took $6.6 \pm 0.2 \mathrm{~min}$ (mean $\pm \mathrm{SE}$ ).

Channel Point FSA analysis. Daily fish presence at the Channel Point FSA was determined by grouping all detections for each individual fish for all receivers over the duration that the tag was monitored into daily bins. If a fish was detected at least once in any particular day it was considered present for that day. Hourly fish presence was determined using the same method as for daily presence, but using hourly bins. Pearson correlation coefficients were used to determine the association between average percent of days and hours fish were present per month and average monthly sea surface temperature $\left(\mathrm{SST}^{\circ}{ }^{\circ} \mathrm{C}\right)$ derived from NOAA satellite data for each tagging period. Fish tagged in December 2004 and April 2005 were combined and 2 fish predominately detected on Receiver 3 ( $\geq 99.8 \%$ detections) were removed for these analyses. The number of fish present per month (excluding tagging month) was also correlated with percent fish presence (days and hours) and SST for the fish tagged in October 2005.

Residency times at the Channel Point FSA were calculated using a residency index $\left(I_{\mathrm{R}}\right)$ (Abecasis \& Erzini 2008). The time-at-liberty residency index $\left(I_{\mathrm{RT}}\right)$ was calculated by dividing the total number of days a fish was detected by the number of days between release and removal of the receivers (time at liberty). The detection period residency index $\left(I_{\mathrm{RD}}\right)$ was calculated by dividing the total number of days a fish was detected by the number of days between first and last detection (detection period). $I_{R}$ varies between 0 (no residency) and 1 (absolute residency).

The temporal periodicity in fish presence at Channel Point was assessed using fast Fourier transformation analysis (FFT) (Cooley \& Tukey 1965 cited in Hartill et al. 2003), a type of spectral analysis that decomposes a regular time series into a finite sum of sine and cosine waves of different frequencies. FFT can only be performed on a time series whose length is a power of 2 (Hartill et al. 2003), resulting in the need to truncate the time series to be examined. FFTs were conducted on the hourly fish presence data for those fish that had sufficient data in one or more blocks of time (11 fish).

Chambers Bay FSA site and acoustic receiver deployment. Chambers Bay FSA site $\left(12^{\circ} 11.4^{\prime} \mathrm{S}\right.$ $131^{\circ} 49.8^{\prime} \mathrm{E}_{\text {; Fig. }}$ 1a) is a shallow $(<10 \mathrm{~m})$ muddy embayment interspersed with small rocky outcrops (Fig. 1c), which can be exposed during spring low tides (Meekan et al. 2008). It is on these scattered outcrops that Protonibea diacanthus aggregate and are captured by commercial fishers. Receivers were placed where fishers catch $P$. diacanthus (Fig. 1c), with 3 placed in the heavily fished region of the bay (Receivers 9 to 11, Fig. 1c). Receiver 10 was never retrieved. Receivers 12 and 13 (Fig. 1c) were placed in a less fished region of the bay (only fished by one commercial fisher) $15 \mathrm{~km}$ from Receivers 9 to 11 to look at inter-FSA movement.

Chambers Bay FSA tagging and analysis. Forty-four fish (TL from 980 to $1250 \mathrm{~mm}$; mean = $1119 \pm 9 \mathrm{~mm}$ ) were tagged at Receivers 10 (33 fish) and 11 (11 fish) in Chambers Bay (see Fig. 1c) between 29 September and 10 November 2005 using the same method as that for the Channel Point fish. Daily fish presence at the Chambers Bay FSA was determined as described for the Channel Point FSA. Due to a lack of data available for this site because of the loss of Receiver 10 where $75 \%$ of fish were tagged (see Fig 1c), no other analyses were performed.

\section{RESULTS}

\section{Receiver range tests}

The maximum effective detection range of the VR2s was $200 \mathrm{~m}$, with 73 to $91 \%$ detection over all range tests. The effect of tide state (neap, intermediate or spring) and phase (high, ebb, low or flood) on detections was inconsistent, with spring and running (ebb and flood) tides having the greatest effect on detections. 


\section{Acoustic monitoring at Channel Point FSA}

Fish were only detected at their respective tagging sites, with $98 \%$ of the total 71951 individual fish detections coming from fish tagged at Channel Point FSA. Of the 40 fish tagged at Channel Point, 30 were subsequently detected for $\leq 327 \mathrm{~d}$. Fish were detected on all of the permanent receivers at the Channel Point FSA, with Receivers 2, 3, 4 and 5 detecting 8, 4, 19 and 22 of the 30 fish detected, respectively. One fish captured and released approximately between Receivers 3 and 4 was detected at Receiver 7, $3.4 \mathrm{~km}$ south of the FSA proper (Fig. 1b).

In general, there appears to have been 3 broad 'fish types' tagged at the Channel Point FSA. (1) Thirteen individuals were present for the majority $\left(I_{\mathrm{RD}} \geq 0.88\right)$ of a short detection period ( 1 to $8 d_{\text {; }}$ see Fig. 2). These fish were last detected $\leq 9 \mathrm{~d}$ after tagging $\left(I_{\mathrm{RT}}<0.05\right)$, with the last detection for 10 of these fish occurring at an 'edge' receiver (Receiver 2, 5 or 7; see Fig. 1b). (2) Five individuals were present for a large portion $(0.64 \leq$ $I_{\mathrm{RD}} \leq 0.87$ ) (Fig. 2) of a 37 to $490 \mathrm{~d}$ detection period. All but one of these fish were tagged in October 2005 and $>95 \%$ of the detections for all 5 fish occurred at a single receiver. (3) Ten individuals were present for a relatively low portion $\left(I_{\mathrm{RD}}<0.34\right.$ ) (Fig. 2) of a 41 to $385 \mathrm{~d}$ detection period. More than $83 \%$ of the detections for this fish type occurred at a single receiver.

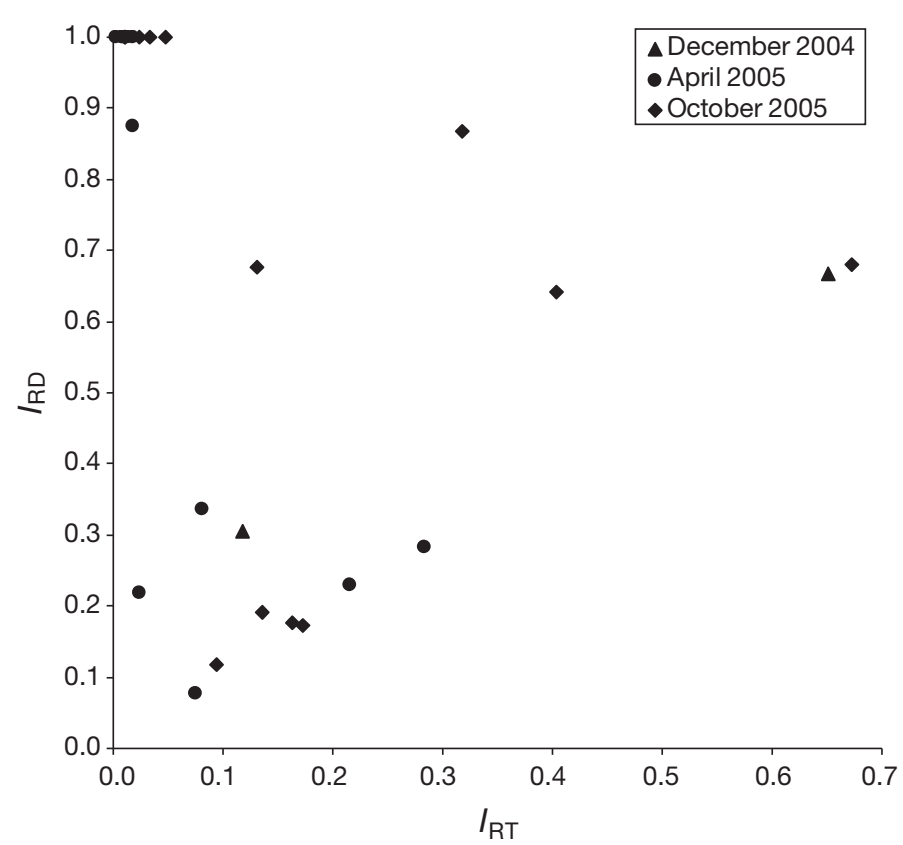

Fig. 2. Protonibea diacanthus. Time at liberty residency index $\left(I_{\mathrm{RT}}\right)$ versus detection period residency index $\left(I_{\mathrm{RD}}\right)$ for each tagging period for Channel Point fish. Fish no. 2 (December 2004) and no. 11 (April 2005) are not represented
A strong positive correlation existed between average percent days and hours per month that fish were present at Channel Point FSA for both fish tagged in December 2004 and April $2005(\mathrm{r}=0.94, \mathrm{n}=17, \mathrm{p}=$ $0.000)$ and those tagged in October $2005(\mathrm{r}=0.94, \mathrm{n}=$ $7, p=0.002$ ) (see Fig. 3a,b). Although the general trend between these measures of fish presence was the same, number of days present was up to $\sim 5$-fold higher than hours present (Fig. 3a,b) for both tagging periods, suggesting that fish were only detected for part of each day.

For the December 2004/April 2005 tagged fish there was a general pattern of high average percent presence in the austral summer of 2004/2005, which declined over the autumn to a low in the winter/spring months, after which it again peaked over the summer (2005/2006) and remained high during autumn 2006 (Fig. 3a,b). As a result of this trend, these fish showed a strong positive correlation between presence and SST (days: $\mathrm{r}=0.68, \mathrm{n}=17, \mathrm{p}=0.003$; hours: $\mathrm{r}=0.66, \mathrm{n}=$ 17, $\mathrm{p}=0.004)$ (Fig. 3a,b).

Fish tagged in October 2005 generally had lower average percent presence than fish tagged in December 2004/April 2005 and average percent presence declined in early summer 2005, then steadily increased to peak in autumn 2006 (Fig. 3a,b). As a result of this trend, these fish showed a negative correlation between presence and SST (days: $\mathrm{r}=-0.83, \mathrm{n}=7, \mathrm{p}=$ 0.021; hours: $r=-0.72, n=7, p=0.071$ ) (Fig. 3a,b). Correlations between the number of October 2005 tagged fish present were all weak (percent days present: $\mathrm{r}=$ $-0.25, \mathrm{n}=6, \mathrm{p}=0.632$; percent hours present: $\mathrm{r}=-0.31$, $\mathrm{n}=6, \mathrm{p}=0.551$; SST: $\mathrm{r}=-0.22, \mathrm{n}=6, \mathrm{p}=0.680$ ), with fish numbers remaining relatively steady throughout the study period (Fig. 3a).

\section{Spectral analysis for Channel Point FSA}

The dominant biorhythm detected by the spectral analyses for Channel Point FSA fish was tidal, with all 11 fish demonstrating either a primary peak at $\sim 12.3 \mathrm{~h}$ (full tidal cycle, 10 fish) or $6.2 \mathrm{~h}$ (half tidal cycle). Six fish demonstrated secondary tidal peaks. There were no other common secondary biorhythms. For all 11 fish the number of detections showed either 1 of 2 general opposite patterns: (1) detections peaked at the ebb tide and declined to be lowest at the flood and high tides (3 fish; see Fig. 4 for example) or, more commonly, (2) detections peaked at the flood and high tides, declining at the ebb and low tides (8 fish; see Fig. 4 for example). For pattern (1), 2 of the 3 fish were predominately $(\geq 99.8 \%$ ) detected at Receiver 3, while, for pattern (2), 5 of the 8 fish were predominately ( $\geq 94.6 \%$ ) detected at Receiver 4. 

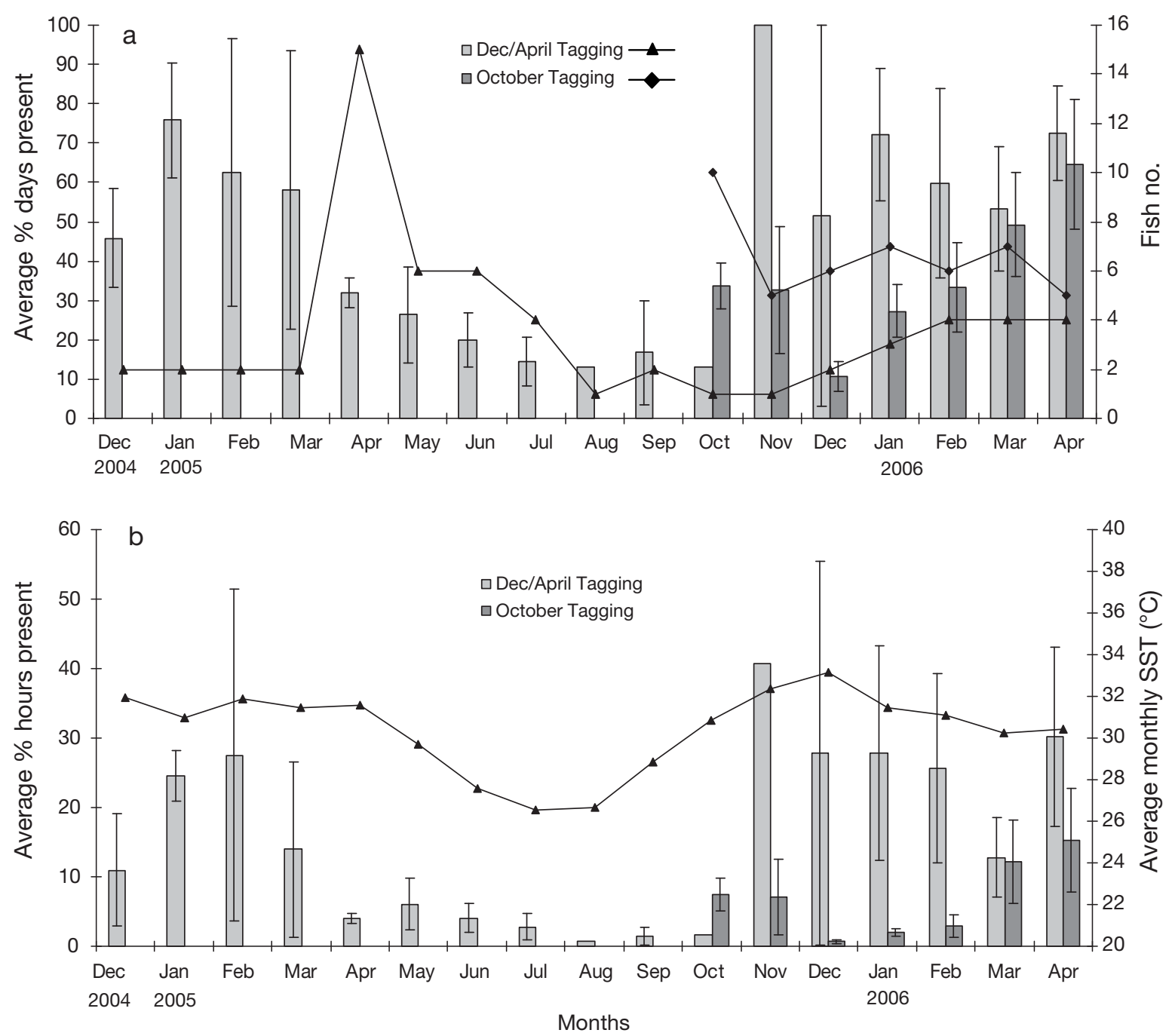

Fig. 3. Protonibea diacanthus. (a) Average percent days (bars) and number of fish (lines) present per month at the Channel Point FSA for fish tagged in December 2004, April 2005 and October 2005. (b) Average percent hours (bars) present per month at the Channel Point aggregation for fish tagged in December 2004, April 2005 and October 2005 and average monthly SST (lines). SST values and number of fish each apply to both (a) and (b)

\section{Acoustic monitoring at Chambers Bay FSA}

Of the 44 fish tagged at Chambers Bay FSA, 19 were detected for $\leq 24 \mathrm{~d}$ (see Fig. 5) at 2 of 4 receivers recovered. Receiver 9 had $71.3 \%$ of all detections, with all 19 fish detected. Receiver 11 only detected 6 fish. Four fish (nos. 41, 58, 70 and 84; see Fig. 5) were recaptured near their release sites in good condition, with the tagging wound well healed, 576, 508, 873 and $43 \mathrm{~d}$ after they were tagged, respectively.

\section{DISCUSSION}

This study has provided important information on the connectivity and dynamics of Protonibea diacan- thus aggregations in the NT. There appears to be little interchange of adult $P$. diacanthus at the spatial scale examined, with individual fish not moving between FSA during monitoring for up to $17 \mathrm{mo}$, including a spawning season. This suggests that the separate FSA examined support separate adult populations.

Despite the lack of interchange found in this study, DNA fingerprinting using the amplified fragment length polymorphisms (AFLP) technique demonstrated no significant genetic variation between Protonibea diacanthus individuals sampled from 2 FSA in North Queensland, Australia (Phelan 2002). Additionally, AFLP analysis of $P$. diacanthus from North Queensland and the NT, suggested that these individuals were also from the same homogeneous genetic population (Phelan 2002). 

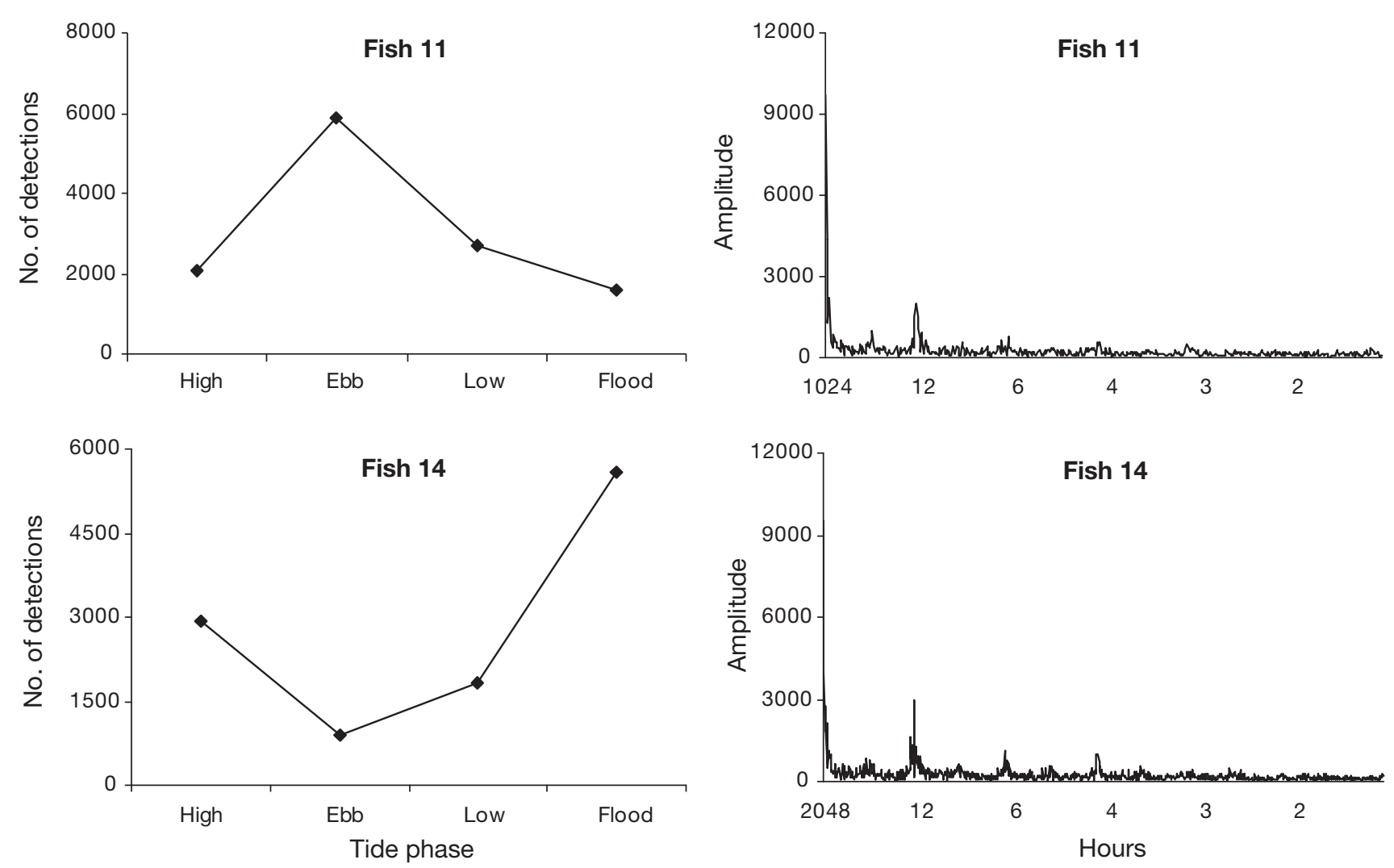

Fig. 4. Protonibea diacanthus. Example of the biorhythmic pattern of detection at Channel Point FSA for those fish showing 'tide phase pattern 1' (fish no. 11) and 'tide phase pattern 2' (fish no. 14), with the number of detections against tide phase in the left panels and the matching fast Fourier analysis of hourly fish presence in the right panels

However, genetic variation can be inadequate for examining population structure where even low levels of adult or larval mixing can occur (Begg \& Waldman 1999). For example, estimates of natal homing in the sciaenid Cynoscion regalis using otolith elemental signatures indicated high spawning site fidelity (61 to $81 \%$, Thorrold et al. 2001); however, there was no genetic divergence between locations, suggesting low exchange rates of individuals between spawning sites was sufficient to prohibit genetic divergence (Cordes \& Graves 2003).

Although the results from the present study suggest that adult interchange between Protonibea diacanthus FSA is limited, given high current velocities at FSA (Meekan et al. 2008) and sciaenid larval durations (Duffy \& Epifanio 1994), it is possible that interchange could occur through dispersal and mixing of larvae. Alternatively, $P$. diacanthus could exhibit high levels of FSA fidelity, as Thorrold et al. (2001) found for Cynoscion regalis. Further studies are needed to determine the natal origins of the separate aggregations of adult $P$. diacanthus in the NT, such as targeted otolith elemental chemistry of both young of the year and adults (e.g. Thorrold et al. 2001).
There was evidence for separate 'fish types' at the temporal scale examined at Channel Point FSA. 'Type 1' fish were only detected for short periods after tagging, but were generally detected each day of that period. Given that the majority of these fish were all last detected on a receiver at the extremities of the aggregation, it is likely that these fish moved away from the aggregation. The 2 remaining types of fish at the Channel Point FSA both had detection periods of greater than 1 mo and exhibited high site fidelity when detected, which has also been demonstrated for other sciaenid species, e.g. Argyrosomus japonicus (Taylor et al. 2006) and Sciaenops ocellatus (Dresser \& Kneib 2007). 'Type 2' fish were detected for the majority of the detection period, with all but one of these fish tagged in October 2005, perhaps as a result of being tagged during the spawning season (August to January). 'Type 3' fish all had multiple periods of absence (days to months) between short periods of presence (days to months). Despite their high site fidelity when present at the FSA, both 'Type 2' and 'Type 3 ' fish may have left the aggregation site during long periods (months) of non-detection.

Multiple 'fish types' appear common in reef fish that are monitored over relatively long periods of time (e.g. 
Fish no.

\begin{tabular}{|c|c|}
\hline 41 & $1,1,111,1$ \\
\hline 46 & $\left.\right|_{\|}$ \\
\hline 49 & 1 \\
\hline 50 & 1 \\
\hline 51 & $ل_{11}$ \\
\hline 52 & $\mid$ \\
\hline 53 & $\perp_{1}$ \\
\hline 54 & 1 \\
\hline 55 & 1 \\
\hline 57 & 1 \\
\hline 58 & $|\quad|\|\|\|\|\|\||\||$, \\
\hline 59 & $\perp_{1}, 1_{1}$ \\
\hline 62 & 1 \\
\hline 66 & $1 \quad 11$ \\
\hline 67 & $\perp_{11}$ \\
\hline 70 & $1,1,1-1$ \\
\hline 74 & म \\
\hline 77 & 1,1 \\
\hline 84 & $\left.\right|_{1}$ \\
\hline & $\begin{array}{llll}\text { Oct } & \text { Dec } & \text { Feb } & \text { Apr } \\
& & 2006 & \end{array}$ \\
\hline
\end{tabular}

Fig. 5. Protonibea diacanthus. Presence or absence of individual fish detected at Chambers Bay FSA. The initial line for each fish represents the day the fish was tagged and each subsequent line represents a day that the same fish was detected

Attwood \& Bennett 1994, Jadot et al. 2002, Starr et al. 2002, Egli \& Babcock 2004). Fraser et al. (2001) suggested that such behavioural polymorphism is the result of the temporal and spatial variability of factors such as mortality risk and foraging success. This is likely to also be the case for Protonibea diacanthus, but may also be related to maximising the chances of spawning success.

For fish tagged in December 2004 and April 2005 at Channel Point there was a general trend of increased presence during the warmer summer and early autumn months, and decreased presence during the cooler winter and spring months. This suggests that some Protonibea diacanthus may be moving away from the FSA, or at least out of the detection range of the receivers for periods of time (days to months) in the cooler months, after which some of them start to move back to the FSA for longer periods, with the majority of fish that had long periods of absence all present by
January 2006. Other sciaenids, e.g. Argyrosomus japonicus (Smale 1985), Atractoscion aequidens (Griffiths \& Hecht 1995), Micropogonias furnieri (da Costa \& Araújo 2003) and Sciaenops ocellatus (Nicholson \& Jordan 1994 cited in Dresser \& Kneib 2007), are most abundant in inshore areas during warmer months where they may spawn (e.g. S. ocellatus, Nicholson \& Jordan 1994 cited in Dresser \& Kneib 2007), moving into deeper offshore waters during cooler months. $P$. diacanthus spawns at the inshore FSA in the NT between August and January, with peak spawning occurring in December and January during the summer monsoon season (Phelan \& Errity 2008). However, it is unknown whether $P$. diacanthus moves into deeper waters in the cooler months.

Protonibea diacanthus tagged at Channel Point FSA in October 2005 showed a different trend to that of the December 2004 and April 2005 tagged fish, with lower monthly fish presence evident for the October fish. This may be because the majority of fish tagged in December 2004 and April 2005 were tagged towards the northern end of the channel, while fish tagged in October 2005 were predominately tagged at the southern end. The bathymetry and morphology of the channel where individual $P$. diacanthus were present is likely to have influenced the ability of the receiver to detect the fish, and also the fish's behaviour (see discussion of tidal influence).

There was a negative correlation between monthly Protonibea diacanthus presence and SST for the October 2005 tagged fish, with presence lowest in the summer months. However, there was no matching trend for fish numbers, which remained steady after the initial decline after tagging. This suggests that detected fish did not move away in summer, but were ranging beyond the detection limit of the receivers more often during this period, perhaps as the result of courtship and spawning behaviour.

The tidal cycle significantly influenced the detection of tagged Protonibea diacanthus at Channel Point FSA, which explains why the number of hours present per month was generally much lower than that for days present. This result is not surprising given velocities of up to $1 \mathrm{~m} \mathrm{~s}^{-1}$ on the ebb tide. Range testing over a monthly tidal regime demonstrated that the relationship between tide and detection rate was not a result of the performance of the receivers declining with tide phase (high, ebb, low or flood) or state (neap, intermediate or spring). The pattern of $P$. diacanthus detections peaking on the running tides conforms to the fishers' 'rule of thumb' for catching these fish: 'no run, no fun'. This suggests that $P$. diacanthus feed on running tides. During tide phases where fish detections were low, the fish may have been close to the channel rock wall at their 'home sites' and, as such, could not 
be easily detected (e.g. Matthews 1992, Bradbury et al. 1997). Similarly, Sciaenops ocellatus monitored using acoustic tracking showed high site fidelity at low tide, with movement occurring on the running tides (Dresser \& Kneib 2007), and the periods of greatest movement of Argyrosomus japonicus coincided with those of their prey (Taylor et al. 2006).

The tidal movements detected in this study were most probably relatively small, as the fish were generally still in the detection range of their home receiver ( 200 m). Similarly, Hartill et al. (2003) demonstrated small tidal movements for Pagrus auratus, with fish occupying relatively small discrete home sites. Numerous studies employing acoustic telemetry have noted distinct tidal movements and/or activity, with the same general movement exhibited during each tidal cycle for both teleost fishes (e.g. Tautoga onitis, Arendt et al. 2001; Liza ramada, Almeida 1996) and sharks (e.g. Carcharhinus plumbeus, Wetherbee et al. 2001; Triakis semifasciata, Ackerman et al. 2000; Carcharhinus obscurus, Huish \& Benedict 1978 cited in Ackerman et al. 2000). Almeida (1996) suggested that these tidal movements occur in the direction of the tide to allow the fish to cover a greater area at a smaller energetic cost.

This may be the case for Protonibea diacanthus at the Channel Point FSA, which explains why some fish were mostly detected on the ebb tide, while others were mostly detected on the flood. Depending on where their 'home site' was in relation to the receivers, fish alternately moved away or towards receivers on each of the running tides, resulting in either a decrease or an increase in detections, respectively. Alternatively, the hydrodynamic conditions created by the specific region of the channel where a fish was found may have dictated when it could leave the shelter of the channel wall. This view is based on the observation that fish detected on the ebb tide were found predominately at the shallow end of the channel, while those whose detections peaked during flood tides were found mainly adjacent to the deepest part. Fine scale (1 to $2 \mathrm{~m}$ ) tracking (e.g. Vemco Radio Acoustic Positioning System [VRAP]), would be needed to determine exactly how $P$. diacanthus at Channel Point move in relation to the tides.

The result of seemingly separate adult populations at each FSA may have significant implications for management of the Protonibea diacanthus resource in the NT, with the potential for each population to be highly vulnerable to localised depletion. Generally it is considered prohibitively expensive to identify all FSA, manage them separately (spatial management) and police them (Claydon 2004, Sadovy \& Domeier 2005). As such, a blanket closure of the resource during the peak summer spawning period would be more practi- cal to manage and enforce, and would protect fish moving in and out of the FSA (Fulton et al. 1999, Claydon 2004, Sadovy \& Domeier 2005). Sadovy \& Cheung (2003) recommended the seasonal protection of spawning Bahaba taipingensis, and important spawning areas for Argyrosomus inodorus in Namibia were protected with seasonal closures (Kirchner et al. 2001). However, given $P$. diacanthus appears to form resident spawning aggregations (see Claydon 2004, Domeier \& Colin 1997), with fish present and caught at the FSA throughout the year (Phelan et al. 2008b), the fish would still be highly vulnerable outside the peak spawning period, reducing the benefits of a closure (Sadovy \& Domeier 2005). As such, other management measures should be examined in combination with seasonal closures, such as reducing catches in the different sectors of the fishery (e.g. A. inodorus, Kirchner et al. 2001).

Acknowledgements. We thank all Tasmanian Aquaculture and Fisheries Institute and NT Department of Primary Industries, Fisheries and Mines staff who assisted in the field, the Paspaley Pearling Company for deploying receivers, N. Hedditch and Arafura Blue Waters Charters for retrieving receivers and S. Richardson, Dundee Blue Water Charters and A. Collins for catching Protonibea diacanthus for tagging. This study was supported by funding from the Australian Government, Fisheries Research and Development Corporation, FRDC 2004/002, awarded to C.D.B. This research complied with current Tasmanian and Australian laws and was approved by the Animal Ethics Committee of the University of Tasmania under Project No. A0008054.

\section{LITERATURE CITED}

Abecasis D, Erzini K (2008) Site fidelity and movements of gilthead sea bream (Sparus aurata) in a coastal lagoon (Ria Formosa, Portugal). Estuar Coast Shelf Sci 79:758-763

Ackerman JT, Kondratieff MC, Matern SA, Cech JJ (2000) Tidal influence on spatial dynamics of leopard sharks, Triakis semifasciata, in Tomales Bay, California. Environ Biol Fishes 58:33-43

Almeida PR (1996) Estuarine movement patterns of adult thin-lipped grey mullet, Liza ramada (Risso) (Pices, Mugilidae), observed by ultrasonic tracking. J Exp Mar Biol Ecol 202:137-150

Apparao T, Lal Mohan RS, Chakraborty SK, Sriramachandra Murty KV, Somashekharan Nair KV, Vivekanandan E, Raje SG (1992) Stock assessment of sciaenid resources of India. Indian J Fish 39:85-103

Arendt MD, Lucy JA, Evans DA (2001) Diel and seasonal activity patterns of adult tautog, Tautoga onitis, in lower Chesapeake Bay, inferred from ultrasonic telemetry. Environ Biol Fishes 62:379-391

Attwood CG, Bennett BA (1994) Variation in dispersal of galjoen (Coracinus capensis) (Teleostei: Coracinidae) from a marine reserve. Can J Fish Aquat Sci 51:1247-1257

Beets J, Friedlander A (1992) Stock analysis and management strategies for red hind, Epinephelus guttatus in U.S. Virgin Islands. Proc Gulf Caribb Fish Inst 42:66-80 
Begg GA, Waldman JR (1999) An holist approach to fish stock identification. Fish Res 43:35-44

Bradbury C, Green JM, Bruce-Lockhart M (1997) Daily and seasonal activity patterns of female cunner Tautogalabrus adspersus (Labridae), in Newfoundland. Fish Bull 95: 646-652

- Cisneros-Mata MA, Montemayor-Lopez G, Roman-Rodriguez MJ (1995) Life history and conservation of Totoaba macdonaldi. Conserv Biol 9:806-814

Claydon J (2004) Spawning aggregations of coral reef fishes: characteristics, hypotheses, threats and management. Oceanogr Mar Biol Annu Rev 42:265-302

Coleman APM (1998) Fishcount: a survey of recreational fishing in the Northern Territory. Fishery Report No. 43. Northern Territory Department of Business, Industry and Resource Development, Darwin

Coleman APM (2004) The national recreational fishing survey: the Northern Territory. Fishery Report No. 72. Northern Territory Department of Business, Industry and Resource Development, Darwin

Coleman FC, Koenig CC, Collins LA (1996) Reproductive styles of shallow-water groupers (Pisces: Serranidae) in the eastern Gulf of Mexico and the consequences of fishing spawning aggregations. Environ Biol Fishes 47:129-141

Cordes JF, Graves JE (2003) Investigation of congeneric hybridization in and stock structure of weakfish (Cynoscion regalis) inferred from analyses of nuclear and mitochondrial DNA loci. Fish Bull 101:443-450

da Costa MR, Araújo FG (2003) Use of a tropical bay in southeastern Brazil by juvenile and subadult Micropoganias furnieri (Perciformes, Sciaenidae). ICES J Mar Sci 60: 268-277

De Bruin GHP, Russel BC, Bogusch A (1994) The marine resources of Sri Lanka. UN FAO, Rome

Domeier M, Colin PL (1997) Tropical reef fish spawning aggregations: defined and reviewed. Bull Mar Sci 60: 698-726

Dresser BK, Kneib RT (2007) Site fidelity and movement patterns of wild subadult red drum, Sciaenops ocellatus (Linnaeus), within a salt marsh-dominated estuarine landscape. Fish Manag Ecol 14:183-190

Duffy JT, Epifanio CE (1994) Effects of larval density on the growth and survival of weakfish Cynoscion regalis in large-volume enclosures. Mar Ecol Prog Ser 104:227-233

Egli DP, Babcock RC (2004) Ultrasonic tracking reveals multiple behaviour modes of snapper (Pagrus auratus) in a temperate no-take marine reserve. ICES J Mar Sci 61: $1137-1143$

Eklund AM, McClellan DB, Harper DE (2000) Black grouper aggregations in relation to protected areas within the Florida Keys National Marine Sanctuary. Bull Mar Sci 66:721-728

Fraser DF, Gilliam JF, Daley MJ, Le AN, Skalski GT (2001) Explaining leptokurtic movement distributions: intrapopulation variation in boldness and exploration. Am Nat 158:124-135

Fulton E, Kault D, Mapstone B, Sheaves M (1999) Spawning season influences on commercial catch rates: computer simulations and Plectropomus leopardus, a case in point. Can J Fish Aquat Sci 56:1096-1108

Griffiths MH, Hecht T (1995) On the life-history of Atractoscion aequidens, a migratory sciaenid off the east coast of southern Africa. J Fish Biol 47:962-985

Griffiths MH, Hecht T (1996) Age and growth of South African silver kob Argyrosomus inodorus (Sciaenidae), with evidence for separate stocks. S Afr J Mar Sci 17: $37-48$
Hartill BW, Morrison MA, Smith MD, Boubée J, Parsons DM (2003) Diurnal and tidal movements of snapper (Pagrus auratus, Sparidae) in an estuarine environment. Mar Freshw Res 54:931-940

> Jadot C, Ovidio M, Voss J (2002) Diel activity of Sarpa salpa (Sparidae) by ultrasonic telemetry in a Posidonia oceanica meadow off Corsica (Mediterranean Sea). Aquat Living Resour 15:343-350

James PSBR (1992) Endangered, vulnerable and rare marine fishes and animals. In: Dehadrai PV, Das P, Verma SR (eds) Threatened fishes of India. Proc Nat Sem Endangered Fish India, National Bureau of Fish Genetic Resources, Allahabad, p 271-295

Kirchner CH, Holtzhausen JA, Voges SF (2001) Introducing size limits as a management tool for the recreational line fishery of silver kob, Argyrosomus inodorus (Griffiths and Heemstra), in Namibian waters. Fish Manag Ecol 8: $227-237$

Matthews KR (1992) A telemetric study of the home ranges and homing routes of lingcod Ophidion elongatus on shallow rocky reefs off Vancouver Island, British Columbia. Fish Bull 90:784-790

Meekan M, Williams D, McLean C, Phelan M (2008) Key habitat characteristics of black jewfish aggregation sites in Northern Territory coastal waters. In: Phelan M (ed) Assessment of the implications of target fishing on black jewfish (Protonibea diacanthus) aggregations in the Northern Territory. Fishery Report No. 91. Northern Territory Government, Department of Industry, Fisheries and Mines, Darwin, p 46-62

Mohan LRS (1991) A review of the sciaenid fishery resources of the Indian Ocean. J Mar Biol Assoc India 33:134-145

Norbis W, Verocai J (2005) Presence of two white mouth croaker (Micropogonias furnieri, Pisces: Sciaenidae) groups in the Rio de la Plata spawning coastal area as a consequence of reproductive migration. Fish Res 74: $134-141$

Phelan MJ (2002) Fishery biology and management of black jewfish, Protonibea diacanthus, (Sciaenidae) aggregations near Injinoo Community, far northern Cape York. Stage 1: initial characterisation of the aggregations and associated fishery. Report to the Fisheries Research and Development Corporation, Canberra

Phelan MJ (2007) Tropical fish aggregations in an indigenous environment in northern Australia. In: Haggan N, Neis B, Baird IG (eds) Fishers' knowledge in fisheries science and management. UNESCO, Paris, p 167-179

Phelan MJ, Elphick D (2006) Coastal line fishery. In: Fishery status reports 2005. Fishery Report No. 85. Northern Territory Government, Department of Industry, Fisheries and Mines, Darwin, p 23-28

Phelan MJ, Errity C (2008) Reproductive biology of black jewfish from Northern Territory coastal waters. In: Phelan M (ed) Assessment of the implications of target fishing on black jewfish (Protonibea diacanthus) aggregations in the Northern Territory. Fishery Report No. 91. Northern Territory Government, Department of Industry, Fisheries and Mines, Darwin, p 22-33

Phelan MJ, Gribble NA, Garrett RN (2008) Fishery biology and management of Protonibea diacanthus (Sciaenidae) aggregations in far Northern Cape York Peninsula waters. Cont Shelf Res 28:2143-2151

Phelan MJ, Campbell D, Humphrey J (2008a) Implications of barotrauma and hook type on catching and releasing black jewfish. In: Phelan M (ed) Assessment of the implications of target fishing on black jewfish (Protonibea diacanthus) aggregations in the Northern Territory. Fishery 
Report No. 91. Northern Territory Government, Department of Industry, Fisheries and Mines, Darwin, p 63-92

Phelan MJ, Errity C, Grubert M (2008b) Description of the black jewfish (coastal line) fishery of the Northern Territory. In: Phelan M (ed) Assessment of the implications of target fishing on black jewfish (Protonibea diacanthus) aggregations in the Northern Territory. Fishery Report No. 91. Northern Territory Government, Department of Industry, Fisheries and Mines, Darwin, p 8-21

Sadovy Y, Cheung WL (2003) Near extinction of a highly fecund fish: the one that nearly got away. Fish Fish 4: 86-99

Sadovy Y, Domeier M (2005) Are aggregation-fisheries sustainable? Reef fish fisheries as a case study. Coral Reefs 24:254-262

Sadovy Y, Eklund AM (1999) Synopsis of biological data on the Nassau grouper, Epinephelus striatus (Bloch 1972), and the jewfish, E. itajara (Lichtenstein, 1822). NOAA Natl Mar Fish Serv Tech Rep 146

Sala E, Ballesteros E, Starr RM (2001) Rapid decline of Nassau grouper spawning aggregations in Belize: fishery management and conservation needs. Fisheries 26(10): $23-30$

Sasaki K (2001) Sciaenidae: croakers (drums). FAO species identification guide for fishery purposes. In: Carpenter KE, Niem VH (eds) The living marine resources of the Western Central Pacific. Vol 5. Bony fishes part 3 (Menidae to Pomacentridae). UN FAO, Rome, p 3117-3174

Saucier MH, Baltz DM (1993) Spawning site selection by spotted seatrout, Cynoscion nebulosus, and black drum, Pogonias cromis, in Louisiana. Environ Biol Fishes 36:257-272

Smale MJ (1985) Aspects of the biology of Agyrosomus hololepidotus and Atractoscion aequidens (Osteichthyes:

Editorial responsibility: Romuald Lipcius, Gloucester Point, Virginia, USA
Sciaenidae) in waters of the south-eastern cape, South Africa. S Afr J Mar Sci 3:63-75

Smith PJ, Francis RICC, McVeagh M (1991) Loss of genetic diversity due to fishing pressure. Fish Res 10:309-316

Starr RM, Heine JN, Felton JM, Cailliet GM (2002) Movements of bocaccio (Sebastes paucispinis) and greenspotted (S. chlorostictus) rockfishes in a Monterey submarine canyon: implications for the design of marine reserves. Fish Bull 100:324-337

Taylor MD, Laffan SD, Fielder DS, Suthers IM (2006) Key habitat and home range of mulloway Argyrosomus japonicus in a south-east Australian estuary: finding the estuarine niche to optimise stocking. Mar Ecol Prog Ser 328: 237-247

Thorrold SR, Latkoczy CL, Swart PK, Jones CM (2001) Natal homing in a marine fish metapopulation. Science 291: 297-299

Trewavas E (1977) The sciaenid fishes (croaker and drums) of the Indo-West-Pacific. Trans Zool Soc Lond 33:253-541

Wetherbee BM, Rechisky EL, Pratt HL, McCandless CT (2001). Use of telemetry in fisheries management: juvenile sandbar sharks in Delaware Bay. In: Sibert JR, Nielsen JL (eds) Electronic tagging and tracking in marine fishes. Kluwer Academic Publishers, Dordrecht, p 249-262

Williams LE (1997). Gulf set net fishery: monitoring and assessment. In: Garrett RN (ed) Biology and harvest of tropical fishes in Queensland Gulf of Carpentaria gillnet fishery. Queensland Department of Primary Industries, Cairns, p 5-28

Zeller DC (1997) Home range and activity patterns of the coral trout Plectropomus leopardus (Serranidae). Mar Ecol Prog Ser 154:65-77

Submitted: May 19, 2009; Accepted: December 22, 2009 Proofs received from author(s): March 4, 2010 